AperTO - Archivio Istituzionale Open Access dell'Università di Torino

\title{
Voting in the aftermath of a pension reform: the role of financial literacy
}

\section{This is the author's manuscript}

Original Citation:

Availability:

This version is available http://hdl.handle.net/2318/1671311

since 2019-01-05T22:58:00Z

Published version:

DOI:10.1017/S1474747218000185

Terms of use:

Open Access

Anyone can freely access the full text of works made available as "Open Access". Works made available under a Creative Commons license can be used according to the terms and conditions of said license. Use of all other works requires consent of the right holder (author or publisher) if not exempted from copyright protection by the applicable law. 


\title{
Voting in the Aftermath of a Pension Reform:
}

\section{The Role of Financial Literacy}

\author{
Elsa Fornero* and Anna Lo Prete ${ }^{* *}$
}

This draft: March $2018 * * *$

\begin{abstract}
This study documents that the electoral cost of major pension reforms is lower in countries where the level of financial literacy is higher. The evidence from data on legislative elections held between 1990 and 2010 in 21 advanced countries is robust when we control for macroeconomic, demographic, and political conditions. Interestingly, these findings are not robust when we use less specific indicators of human capital as general schooling, supporting the view that knowledge of basic economic and financial concepts has distinctive features that may help reduce the electoral cost of reforms having a relevant impact on the life-cycle of individuals.
\end{abstract}

JEL classification: D72; H5; I2.

Keywords: pension systems; reforms; re-election; financial literacy.

\footnotetext{
* University of Torino and CeRP - Collegio Carlo Alberto; email: elsa.fornero@unito.it. ** University of Torino and CeRP - Collegio Carlo Alberto; email: anna.loprete@ unito.it. *** We thank: Roel Beetsma, Anne Lavigne, Muriel Roger, and Giovanni Gallo for their constructive comments; participants in the Netspar International Pension Workshop (Leiden, January 2017), «La Sapienza» seminar (Rome, February 2017), the 10th Financial Risks International Forum (Paris, March 2017), the Workshop on Household Finance and Economic Behaviour (Turin, May 2017), the 15th International Conference on Pension, Insurance and Saving (Paris, May 2017), and the Workshop on Retirement: Public Policy Evaluation (Annecy, June 2917) for useful discussion; Antoine Bozio, Tabea Bucher-Koenen, Agnieszka Chlon-Dominczak, Robert Gal, Robert Holzmann, Mauro Mastrogiacomo, Theo Nijman, Ed Palmer, Steinar Strøm, Tarmo Valkonen, Frank Vandenbroucke for their help on specific pension reforms; the referees and the editor for helpful comments and suggestions. The usual disclaimer applies.
} 


\section{Voting in the Aftermath of a Pension Reform: \\ The Role of Financial Literacy}

\section{Introduction}

Reforms involving important financial consequences for family budgets are often viewed as difficult to implement, because the burden that they impose on citizens can make a government unpopular, regardless of its goals. Jean-Claude Juncker, the current President of the European Commission, expressed this concern in a much-quoted aphorism: "We all know what to do, but we don't know how to get re-elected once we have done it" (The Economist, 15 March 2007).

In this paper, we explore whether the electorate's ability to understand essential economic concepts may be a relevant element for the evaluation of the "electoral costs" of economic reforms that typically require sacrifices today in expectation of benefits tomorrow and that have a relevant impact on individuals' life cycle. Specifically, we focus on the major restructuring of pension systems that has taken place in advanced countries in the past decades. We study whether the probability of a government being confirmed in office is associated with the signing into law of a pension reform during its term of office and with indicators of the degree of basic economic and financial knowledge among the population.

Research on the association between economic reforms and electoral outcomes in advanced countries does not decisively support the view that a "political toll" exists. For instance, Alesina et al. (2013) find no evidence of a clear relation between large fiscal adjustments and the probability of a government being re-elected in OECD countries. Buti et al. (2010), who analyse the impact of deregulation in five policy areas using the database on reforms developed by Duval (2008), show that the re-election of the incumbent government is not affected by reforms when a synthetic index of reformist attitudes in all policy areas is 
adopted. The results are at best mixed when different types of reforms are considered: the association is mildly positive for tax wedge and unemployment benefit cuts and mildly negative for reforms of employment protection and retirement schemes.

Related works study why it is difficult for a government to carry out economic reforms and analyse the conditions under which policy changes are most likely to occur. Alesina et al. (2006) use a "war of attrition" model whereby the political conflict between two generic groups in the society delays fiscal stabilization after a negative permanent shock to the economy. They show that reforms targeting the stabilization of large budgetary deficits or of the inflation rate are more likely to occur in times of economic crisis, after the appointment of a new government, and when the government is stronger. Dias da Silva et al. (2017) consider European Union member states and find that the probability of implementing structural reforms is higher during deep recessions and in periods of high unemployment, a result that is stronger for changes in employment protection legislation. Prati et al. (2013) show that there is a positive, albeit very heterogeneous across countries, association between reforms of real and financial markets and growth. Deregulation of real and financial markets is also positively associated with economic uncertainty, measured by stock market volatility, according to Bonfiglioli and Gancia (2016).

In this work, we focus on the electoral cost of reforms that introduce structural modifications into people's economic life cycle and are likely to receive prolonged front-page media attention, as is arguably the case for major changes to the pension system or to the labour market. We concentrate specifically on a set of policy changes that represent a key public policy issue in advanced countries, that is, on "major" reforms to the pension system. Accordingly, we collect information on those laws that are universalistic in their scope and that, according to international organizations such as the Organisation for Economic Co-operation and Development (OECD), the International Monetary Fund (IMF), and the World Bank (WB), are 
targeted at improving financial sustainability by reducing future pension spending without putting the adequacy of retirement incomes at risk.

The specific dimension of knowledge that financial literacy indicators capture can arguably relate to people's understanding of reforms to the pension system. Pensions are a very important topic for everybody, but they are also rather difficult to understand, especially in public systems in which the correlation between the contributions paid in and the benefits received at the individual level can be rather loose. People may tend to interpret pensions as an individual right instead of the result of (compulsory) savings accumulated in the working period. Since reforms in general try to reinforce that relationship, a basic understanding of what a pension is and how a pension system works is needed. This understanding requires some basic economic and financial knowledge (like the notions of accumulation, compound interest, debt, and risk diversification) and may help government re-election. Pension reforms are widely discussed and sometimes very much resented and opposed. However, if the reform is needed, for example because the current system is no longer sustainable and fair, one should expect people who understand its basic principles to be less opposed to it.

We find no robust evidence, as in Alesina et al. (2013), of a clear relationship between reforms and re-elections per se. The situation changes, however, when we take into account the level of basic economic and financial knowledge among the population. The electoral cost of a pension system reform appears to be significantly lower in countries where the level of economic and financial knowledge among the population is higher. We also consider other indicators of human capital and test their role as explanatory variables, finding no relation between these indicators and the electoral cost of major pension reforms. The results suggest that economic and financial knowledge has distinctive features that more general dimensions of education, such as school attainment, do not capture. 
Our paper is part of the growing literature on the importance of economic and financial knowledge to people's decision making. Recent studies by, for example, Lusardi and Mitchell (2007, 2014), Bucher-Koenen and Lusardi (2011), Fornero and Monticone (2011), and Van Rooij et al. (2011) show that economic and financial literacy helps to explain people's ability to accumulate and manage wealth and build retirement plans. Poor financial literacy is also associated with a lack of portfolio diversification in both country studies (Guiso and Jappelli, 2009) and cross-country research (Jappelli, 2000; Giofré, 2017). People's ability to take advantage of new investment opportunities, measured by economic literacy, may help to reduce inequality across countries and over time (Lo Prete, 2013, 2018). Little has been undertaken so far to include economic and financial knowledge in models that study why governments are reluctant to introduce economic reforms. Experimental evidence on Portuguese voters suggests that people's willingness to support pension reforms is related to the information that they gather (Fontoura Gouveia, 2017), while, in a recent work on data from the British Election Study, financial literacy seems to be associated with less favourable attitudes towards redistributive policies (Montagnoli et al., 2017).

Of course, financial literacy is not the only ingredient necessary to implement economic reforms successfully. Nevertheless, it appears to be a relevant one in our empirical models, in which we control for macro-economic conditions, demographics factors, and the characteristics of the political system. Our findings contribute to the research on the association between reforms and re-election in advanced countries, with an innovative feature that emphasizes the role of economic and financial knowledge in the success of reforms. At the same time, this work adds a new element to the research on financial literacy, by focusing on its relevance to political choices, and offers a qualitative taxonomy of pension reforms for cross-country comparisons of major changes to the pension system. 
The paper is organized as follows. In Section 2, we define the variables that we use in the empirical analysis. In Section 3, we provide some descriptive evidence and present the empirical strategy. In Section 4, we reveal the empirical findings and test their robustness. Concluding remarks are provided in Section 5.

\section{Data and variables' definition}

In this section, we define the variables that we use in the empirical analysis. Our data set covers the period 1990-2010. It includes information on pension reforms, the electoral outcomes of parliamentary elections, financial literacy, and other dimensions of education, as well as macroeconomic, demographic, and political conditions, for 21 OECD countries. The countries in the sample are Austria, Belgium, Canada, the Czech Republic, Denmark, Finland, France, Germany, Greece, Hungary, Ireland, Italy, Japan, the Netherlands, Norway, Poland, Portugal, the Slovak Republic, Spain, Sweden, and the United Kingdom.

Re-election. Following previous studies on the association between electoral outcomes and reforms (Brender and Drazen, 2008; Buti et al., 2010), we define "re-election" as a dummy variable to which we assign the value one if in year $t$ an election takes place and the head of the government that held office before the election is confirmed in office and the value zero if a new head of the government is appointed. By considering who was in power before and after the election, our definition of re-election accounts for the possibility that a cabinet reshuffle that resulted in the appointment of a new head of the government belonging to the same party (e.g., the appointment of Major as UK Prime Minister after Thatcher's resignation in 1990) or to a different party (e.g., the appointment of Bruton as Taoiseach of Ireland in 1994, after the formation of the "Rainbow Coalition") occurred during the legislature. We do not distinguish whether such changes were due to the resignation, retirement, or death of the head of the government who held power at the beginning of the legislature that ends with the election in 
year $t$. What is relevant for our purposes is to rule out the possibility that the political toll of the reforms under analysis was paid before the elections by a different head of the government from the one who signed a reform into law. This is actually the case in our sample, in which cabinet reshuffles never occurred during a legislature that witnessed the ratification of a major pension reform.

Pension reforms. We build our pension reform variable following an approach based on expected rather than effective results and consider whether a "fundamental" (structural) pension reform was introduced by the incumbent government. More specifically, we define as "major" a pension reform that satisfies both the following criteria:

(a) introduces a structural change that - according to the evaluations of international institutions (such as the OECD, the WB, or the IMF) - has an impact in terms of financial sustainability and/or income adequacy; and

(b) has a broad scope, that is, affects the generality of workers and not only specific categories, including reforms that aim to achieve greater integration of the public and private pillars of retirement systems.

The resulting reform variable takes the value one if a major change in the pension system was signed into law during the legislature and zero otherwise. Table A.1 reports the number of legislative elections and the number of major pension reforms by country. The list of major pension reforms is presented in Table A.2 (details of the characteristics of the reform events that we consider and of their evaluation by international organizations are available in the Online Appendix to this paper). 
Our definition has the advantage of ruling out minor changes to formulae and other technical features characterizing the pension rules (so-called "parametric" reforms ${ }^{1}$ ) that are not central to the pension system and that, as it is reasonable to expect, are less likely to receive widespread media coverage and voters' attention. A similar attempt to distinguish between "marginal" and "structural" pension reforms is made by Fondazione Rodolfo De Benedetti and the IZA based on a scope criterion; specifically, they consider changes to the generosity of public pension systems that modified the monetary amount of pensions or the eligibility criteria for the generality of workers. We build on their effort by explicitly taking into account the sustainability and adequacy perspectives to evaluate the reforms under analysis and by enlarging both the country and the period sample.

An alternative approach to the definition of the reform variable would be to consider effective results and measure the impact of pension restructuring on the household sector and on public finances. It is difficult to find statistics on changes such as the reduction in households' pension wealth (i.e. implicit public debt, for a pay-as-you-go (PAYG) system) or in the internal rate of return on contributions resulting from a reform and to arrive at clear-cut definitions. For instance, in Duval's (2008) study on the role of macroeconomic policy in fostering structural reforms in labour and product markets, the author constructs an index of major reforms in old-age pension schemes by considering one of the few data series available for cross-country comparisons. He uses an average of OECD measures of implicit tax rates on continuing work and defines as "major" a change in the resulting indicator that was greater than two standard deviations of its annual change over all the observations considered in the

\footnotetext{
${ }^{1}$ Our taxonomy does not entirely correspond to the usual distinction between "structural" and "parametric" reforms, as some parametric reforms have a profound impact on sustainability/adequacy and may thus be considered as "major".
} 
study. This methodology allows a very limited number of reform events to be identified as "major" and, when used by Buti et al. (2010) to assess the association between reforms and reelections, constrains pension reforms to have an electoral cost only after they became effective - which could be many years after their implementation, depending on the length of the phasing-in period. ${ }^{2}$ Instead of relying on effective changes in money's worth measures of pension programmes (such as replacement ratios, the internal rate of returns, and the net worth), we focus on people's perceptions of the net costs (benefits) of a reform and investigate whether voting behaviour is directly affected by the enactment of a pension reform.

Financial literacy. Financial literacy is generally referred to as the ability to understand basic economic concepts concerning individual financial decisions and the functioning of a modern economy (Lusardi and Mitchell, 2014). To compare the level of financial literacy (FL) across countries, we use an indicator provided by the IMD Business School in Lausanne, published in the IMD World Competitiveness Yearbook. The information on economic and financial knowledge that it gathers from the Executive Opinion Survey conducted by the IMD Business School is based on interviews conducted with senior representatives of the national business community who are asked to evaluate the level of economic and financial knowledge among the population on a scale from 1 to 10 .

Of course, indicators obtained from indirect surveys of interviewees may convey subjective biases. However, the IMD Business School's indicator has the notable advantage of

\footnotetext{
${ }^{2}$ Duval (2008) classifies only eight changes as major reforms to retirement schemes in the 21 OECD countries over the 1985-2003 period that he considers. The timing of such changes depends on the enforcement of specific measures that might have been phased in years after the reform package that they belong to was voted into law and placed before the people in polling stations.
} 
being available for a large number of countries from the mid-1990s until the late 2000s. Recent macro-economic analyses on the relevance of FL to stock market participation (Jappelli, 2010) and inequality (Lo Prete, 2013, 2018) exploit its country and time coverage. A more recent direct indicator compiled through national surveys is the financial literacy score of the Programme on International Student Assessment (PISA) of the OECD. It assesses 15-year-old students' experience with and knowledge about money. Unfortunately, data are available only for a few countries and for recent years that are outside our reference period. We consider the PISA score in FL as a robustness check anyway, to show that our results are robust to alternative measures of FL.

Other indicators of education. Several dimensions of human capital accumulation may affect people's understanding of public policies. To investigate whether FL has distinctive features with respect to other dimensions of education, we also consider OECD-PISA data on the level of "mathematical literacy". They are based on the assessment of mathematical performance of 15-year-old scholars. The PISA score in mathematical performance aims to measure the level of skills that should enable people to make well-founded decisions on daily issues involving some mathematics, as could be the case for the evaluation of a pension reform. Although the surveyed students do not yet participate in parliamentary elections and may thus only marginally be interested in pension reforms, a caveat that also applies to the PISA score in FL, it could be argued that, where the PISA scores are higher, the financial literacy of parents is also higher. Finally, we consider more generic indicators of human capital - secondary and tertiary school attainment, as measured by Barro and Lee (2013) - to account for the percentage of people who have achieved a secondary or a tertiary school degree, respectively.

Control variables. The probability of a government being re-elected may depend on several macro-economic, demographic, and political factors that are not directly related to the 
reform process under analysis or to financial literacy. In the last part of this section, we list the set of control variables that we use.

With regard to macro-economic conditions, we test whether people living in countries that experience periods of higher economic growth, expansionary fiscal policies, and lower inflation are keener to re-elect the incumbent government. To control for the spurious effects of the level of economic activity in the years before the elections, we include the output gap to GDP ratio and its change. To account for changes in fiscal policy and price-level dynamics, we control for the change in the primary cyclically adjusted balance and for yearly changes in inflation, respectively. As regards demographics, we control for the possibility that electoral outcomes differ across countries because of different age profiles of the population by including, as a proxy for the age of the median voter, the "median age" of the total population. As a robustness check, we also test whether the probability of a government being re-elected in the aftermath of a pension reform is higher in younger societies because young people may care more about long-term debt sustainability. ${ }^{3}$

We include information on the main aspects of the political system and electoral rules using data drawn from the Database of Political Institutions (DPI) by the World Bank (see Beck et al., 2001; Cruz et al., 2016). Like other studies on the determinants of re-election, we consider some characteristics of the political system, such as the presence of proportional versus majoritarian voting rules, parliamentary versus presidential systems of government, and

\footnotetext{
${ }^{3}$ The median age of the total population is an imperfect proxy for the age of the median voter. It is important to recall that youth abstention from the polls is a source of concern in modern democracies and that older people turn out to vote more than middle-aged and young voters (Glenn and Grimes, 1968, and related literature).
} 
differences in the frequency of elections due to the constitutional term of office of the elected chambers.

Next, we consider information on the incumbent government. To measure its power to implement policies, we use the "margin of majority" that it enjoys over the opposition parties, defined as the share of seats held by the parties supporting the government. The political orientation of the government may also be important in testing whether the electoral cost of a reform differs across parties due to their ideological connotation. For instance, one may expect a left-oriented government to lose more support if it becomes involved in reforms that impose a burden on all citizens irrespective of their income or wealth level. To represent political orientation, we define "left-oriented" as a government of which the head is from a Communist, Socialist, or Social-Democratic party. Finally, to account for the "stability" of the government, we consider the percentage of veto players (i.e. political forces who were formerly members of the government coalition) who left the government in the year before the elections.

We also control for other macro-economic and political factors that might affect the reelection probabilities in the aftermath of a pension reform. We consider whether the re-election probabilities are affected by the level of the real GDP and real GDP per capita, the unemployment rate, the level of government debt, and lags of some of the independent variables. As regards political conditioning factors, we investigate whether the electoral cost of a reform depends on political and civic support for the reform process. ${ }^{4}$ To include information on the political distance between the main parties elected at the national level, we

\footnotetext{
${ }^{4}$ As discussed in the literature on framing, not only the content but also the tone of public debates can matter to electoral outcomes (see, e.g., Chong and Druckman, 2007). Information on the nature, content, and intensity of policy-related discussions is difficult to gather. When data from qualitative analyses are missing, we consider other political conditioning factors.
} 
use a measure of "polarization". It takes the value zero if the party of the head of the government has an absolute majority and otherwise it measures the maximum distance in political orientation between the party of the head of the government and the largest opposition party. Then, we try to account for the possibility that people's perception of a higher cost of ageing may create more sympathy for a reform and reduce its electoral costs. To this end, we include the difference between the 30-year projection of the old-age dependency ratio and its current level. We also control whether this effect is less relevant in countries where the pension system is more similar to a fully funded system (FF) than to a PAYG system by controlling for the type of the pension system. Pension systems in advanced economies are either strictly PAYG - with no reserves and often with deficits (i.e. the contributions are lower than the expenses) that need to be covered by general taxation or the issuance of new debt - or multipillar systems consisting of a predominant PAYG system and typically private pension funds. None of the countries in our sample can be classified as FF. Nevertheless, we control for the fact that the Netherlands, Canada, the UK, and, to a lesser extent, France, are countries where pension funds are more important.

Finally, we consider how early in the legislature the reform was introduced and whether a country has a greater tradition of re-electing the incumbent head of the government. As a proxy for the latter, we include among the regressors the maximum number of years for which a head of the government has been in office. According to the DPI data, this variable ranges from 5 years in countries like Japan and France to 16 years in Helmut Kohl's Germany.

\section{Descriptive evidence and empirical strategy}

This section provides some background information on elections, reform events, and the FL indicator that we use. Then, it presents the empirical strategy that we follow. 
In the sample of advanced countries that we consider, 118 parliamentary (general) elections took place between 1990 and 2010. The sample is unbalanced for several reasons. Election calls are of course not synchronized across countries. The constitutionally defined length of tenure is different and ranges between 4 and 5 years in our sample. Early dissolution of the legislature occurred 46 times and at least once in every country of the sample, with the exceptions of Finland, Hungary, and Norway. Focusing on electoral outcomes, the head of the government was elected for a second term of office in 49 election rounds out of 118 . The head of the government was confirmed in office more frequently in Austria, Belgium, Canada, Denmark, and Germany, where re-election occurred four times in the period under analysis. In contrast, in Italy, France, Hungary, and Poland, the head of the government was never reelected during the period under analysis.

Between 1990 and 2010, 28 elections were held in the aftermath of major changes to the pension system. According to our taxonomy, we classify as "major" the pension reforms listed in Table A.2. It is possible that the same government implemented more than one pension reform act in the same legislature, like the Schussel Government in Austria, or that a change in the pension system was implemented by a series of legislative acts dealing with different aspects of the system, as was the case in Hungary in 1997, the Slovak Republic in 2003-2004, and Finland in 2005. We study the electoral costs of structural changes to the pension system that have a major impact on people's life and on public finances. Fiscal consolidation measures receive more front media attention than policy innovations in other areas, especially at times when pension expenditures and demographic pressures challenge public debt sustainability. Acknowledging that perceptions and penalties may differ when a pension reform is part of a broader reform package, we assume that the electoral costs of a major pension reform are orthogonal to those of innovations in other policy areas, leaving to future research the task of studying policy complementarities theoretically and empirically. To relate electoral outcomes 
to the introduction of major changes to the pension system, we consider whether at least one major pension reform was signed into law before the election day.

We do not distinguish explicitly between contractionary and expansionary reforms, but the sample period that we consider (1990-2010) is largely the period of the pension reform process, with almost all countries being involved in pension restructuring with more rapid or lengthy phasing in. Reforms were generally introduced to improve the financial sustainability of pension schemes, threatened by population ageing, poor design, and "excessive" political generosity towards current generations. This does not prevent some aspects of the restructuring package carrying a positive sign for some specific groups of people. Nevertheless, looking at the overall framework, all the reforms in the sample were of the restrictive type - that is, they implied a retrenchment of past promises - and none of them has been reversed substantially. The pension formula was typically DB (defined benefits), but one of the features of the reform process of the last two decades has generally implied a move towards a stronger correlation, at the individual level and evaluated at the present actuarial level, between contributions paid and benefits received, that is, towards a less generous type of DC (defined contribution) formula. This is indeed, together with increases in the average retirement age, one of the two fundamental characteristics of the reform process. Some countries undertook this in a more direct way, by adopting the Notional Defined Contribution system (Sweden, Italy, and Poland); others, like France and Germany, attempted it more indirectly by recurring to a point system, with no automatic actuarial correction for the age of retirement.

We also included in our list the privatization of the Dutch public pension fund ABP and the reform of the Finnish ITP occupational pension plan in 2007, to acknowledge the relevance of occupational plans in the countries considered - a choice that does not affect our findings, which are robust to the exclusion of these two reform events from the sample. Finally, as the 
footnote to Table A.2 remarks, we record no major pension reforms over the period under analysis in three countries, namely Denmark, Greece, and Ireland.

\section{Figure 1 here}

To show some features of the variables under analysis, in Figure 1 we plot the frequency of pension reforms on the horizontal axis and the frequency of re-election on the vertical axis. In our sample, there is a slightly negative association between the percentage of elections that resulted in the re-election of the incumbent government and the percentage of elections that took place after a major change in the pension system. Interestingly, the countries that have reformed more are also those in which the governments have paid higher electoral costs, with the notable exception of Germany, where the reforms are associated with a high probability of the incumbent government being re-elected. ${ }^{5}$

Figure 2 here

Figure 3 here

As regards financial literacy, Figure 2 shows the level of FL across countries using the financial literacy indicator from the IMD Competitiveness Yearbook. FL literacy is higher in Scandinavian countries, Ireland, Japan, and the Netherlands. In Southern and Eastern European countries, the level of FL is lower, in line with the evidence obtained from using another measure (i.e. the OECD-PISA score in FL for the few countries for which it is available). In Figure 3, we show that the level of FL has not changed much over time. FL, which is measured on a scale from 0 to 10 , declined by only 0.18 points between 1995 and 2008 when we consider its sample average. Within countries, the differences between the initial and the final record of

\footnotetext{
${ }^{5}$ The results in Section 4 are robust to the exclusion of Germany from the sample.
} 
FL literacy in absolute values are lower than 1 in all countries but Japan and the Slovak Republic. ${ }^{6}$

\subsection{Empirical specification}

We study the determinants of a parliamentary re-election (REEL) in country $j$ at time $t$ in empirical models that read as follows:

$$
R E E L_{j t}=\alpha+\beta P R E F_{j t}+\gamma\left(P R E F_{j t} \times F L_{j t}\right)+\delta F L_{j t}+X_{j t} \theta+\varepsilon_{j t}
$$

We consider whether a major pension reform $(P R E F)$ was signed into law in year $t^{\prime}$, where $\mathrm{t}-\mathrm{n} \leq \mathrm{t}^{\prime} \leq \mathrm{t}$ and $\mathrm{n}$ represents the constitutionally specified term of office of the legislature. ${ }^{7}$ Then, we test whether the slope of the relationship between reforms and re-election differs across countries in ways that depend on the average level of financial knowledge among the population $(F L)$. If FL helps to explain the association between re-election and pension reforms, we expect the coefficient of the interaction term, $\gamma$, to be significantly different from zero; otherwise, it is zero.

The $X_{j t}$ set of control variables in model (1) includes macro-economic and demographic variables, country-specific characteristics of the political system, and indicators of the power, political orientation, and stability of the incumbent government. To account for the fact that

\footnotetext{
${ }^{6}$ The Slovak Republic is the only country in our sample for which FL was compiled by the IMD Competitiveness Yearbook starting in 2001 and not in 1995. We control for the potential role of outliers of both the Slovak Republic and Ireland, finding that dropping these two countries from the sample does not affect our results.

${ }^{7}$ If the legislature is interrupted $s$ years before its constitutionally defined conclusion, the inequality becomes $\mathrm{t}+\mathrm{s}-\mathrm{n} \leq \mathrm{t}^{\prime} \leq \mathrm{t}$, as we consider reforms that occurred within the term of office of the elected chambers, regardless of its length.
} 
people are more likely to consider recent events when casting a ballot in national elections, we average the macro-economic and demographic conditions over the current (election) year and the previous year (see also Fair, 1978; Brender and Drazen, 2008; Buti et al., 2010). To measure people's understanding of the economic content of reforms that may have been signed into law up to four years before the call of the election scheduled at time $t$, and to reduce the potential measurement errors, we use the four-year moving average of the indicators of education (see the Data Appendix for details). In the next section, we will show that our results are robust to alternative timings of these independent variables.

As discussed by Angrist and Pischke (2009) and in related literature, ordinary least squares (OLS) estimators can be preferable to non-linear estimators when running regressions on panel data and when using instrumental variables. This is the case in our paper. In our empirical exercise, we use linear probability models and instrumental variables (IV) techniques to relax the assumption that reforms are exogenous to re-election probabilities. We also show that the main results from OLS estimators are similar to the results that we obtain from Probit estimators.

\section{Results}

We start by considering the bivariate association between the probability of a government being re-elected and the introduction of major changes to the pension system. The OLS estimates in the first column of Table 1 confirm, in the context of our study, the previous results obtained by Alesina et al. (2013). The probability of the incumbent government winning the elections is not significantly related to the introduction of a reform during its years of office. ${ }^{8}$

\footnotetext{
${ }^{8}$ The association between the pension reform variable and the probability of the head of the government being re-elected becomes mildly significant in specifications in which we include
} 
In the second column of Table 1, we allow the relation between reforms and electoral outcomes to differ across countries that have different levels of FL among the population. The introduction of the interaction term between FL and the pension reform variable provides interesting insights. FL is significantly associated with the probability of confirming the head of the government for a second term of office not per se - its main effect not being estimated as significant - but because of its interaction with the pension reform variable. Like Buti et al. (2010), who consider a very narrow set of changes in the pension system, pension reforms are negatively associated with re-election probabilities, but, interestingly, in our data, this effect is mediated by people's ability to understand basic economic and financial concepts.

The positive sign of the coefficient of the interaction term between $P R E F$ and $F L$ indicates that, in countries where the population is more financially literate, the electoral cost of a pension reform is lower. To provide an interpretation of the magnitude of the key coefficients, we need to consider the level of FL. The total effect of introducing a pension reform on the probability of the head of the government being re-elected is measured by $\beta+$ $\gamma \mathrm{FL}_{\mathrm{jt}}$ in equation 1 . Based on the results from the linear probability model in column 2 of Table 1, enacting a pension reform changes the probability of the head of the government being reelected by 15 percentage points for a country with an average FL (5.33 in our 118 country sample). Considering that FL ranges between 2.84 and 7.96 in our data, the results imply that the probability of re-election changes by -51 percentage points for a country with the lowest value of FL and by 100 percentage points for a country with the highest value of FL. This is an

the set of control variables listed in column 3 of Table 1 . However, this finding is not robust to minor changes in the set of control variables or in the inclusion of country and time effects (results not reported). 
important indication of the relevance of the association under analysis. Although the results from linear probability models should be interpreted with some caution, our estimates suggest that the electoral gains from investing in financial literacy are sizeable.

In the following analyses, we test whether the results from the simple model in column 2 hold when we account for other factors that may be relevant to re-election probabilities. In the next columns of Table 1, we include control variables for macro-economic conditions, demographics, and features specific to the political system and to the incumbent government. In the smaller sample, which the data availability allows us to inspect, ${ }^{9}$ our main findings hold. Re-election probabilities are negatively related to pension reforms, and FL plays a role in explaining this association. Re-election probabilities are also significantly associated with some control variables. The positive association with the level of the output gap indicates that the incumbent government has more chances of winning the elections in times when the economy is working above its potential, that is, in good times, in line with the results of Brender and Drazen (2008) and Buti et al. (2010). The probability of a government being re-elected is also higher for governments that have lost a lower number of veto players, that is, more stable governments, and for governments that have enjoyed a greater margin of majority ( $\mathrm{p}$ value $=0.104)$, as in Alesina et al. (2006). Re-elections are less likely in countries where the median age of the population is higher and in presidential systems. The results regarding the association between reforms, FL, and re-election also hold in specifications in which we include time effects (column 4), country effects (column 5), and country and time effects (column 6). Tests of the joint significance of the time and country effects indicate that only the set of time effects in column 4 is significantly different from zero. Finally, in the last column

\footnotetext{
${ }^{9} \mathrm{We}$ lose observations because information on the output gap and the government balance is not available in the early 1990s for Germany, Eastern European countries, and Greece.
} 
of Table 1, we compute Probit average marginal effects and show that our results from the linear probability models are also confirmed when using non-linear estimation methods. In the following analyses, we will test the robustness of the findings to endogeneity issues and perform other robustness checks, using linear probability models, including the set of control variables in column 3 of Table 1, and we will explore and discuss the role of time-specific exogenous effects.

\subsection{Endogeneity issues}

So far, we have made the implicit assumption that reforms are exogenous to re-election probabilities. As we discussed in Section 2, the pension reform process, over the two decades that we consider, was targeted to improve the sustainability of pension schemes. If changes that increase the generosity of the pension scheme are arguably motivated by electoral concerns, retrenchments are hardly driven by a desire to increase the popularity of the government within the electorate. Still, we cannot rule out the possibility that endogeneity issues will arise and bias our estimates.

As our first exercise, we follow Buti et al. (2010) and run regressions on the sub-sample of countries that belong to the European Union (EU) and on the years that followed the signing of the 1992 Maastricht Treaty. The argument for this estimation strategy is that those Maastricht criteria, and the limitations that they imposed on the discretionary national policies of the EU member countries, may help in considering the subsequent reforms as exogenously spurred by common developments rather than as the result of nationally driven interests. The results are presented in the first column of Table 2. The negative association between pension reforms and re-election probabilities and the positive sign of the interaction term between the pension reform variable and the FL indicator hold in the smaller 1992-2010 sample of EU member states.

\section{Table 2 here}


Next, we use instrumental variables (IV) techniques. It is admittedly difficult to find good instruments for our pension reform variable. To isolate the exogenous (to re-election) component of major policy changes to the pension system, we include in the set of instruments country-specific indicators of the welfare state typology, their interactions with the exogenous forces driving pension systems' reforms over time, the age of the pension system, and a variable that accounts for the introduction of supranational constraints on discretionary policies in EU member states.

To provide more details about our instruments, the welfare state (WS) typology is a country-specific time-invariant characteristic that aims to capture different attitudes towards pension system reforms. We define it on the basis of historical roots and common traits of welfare states and identify five models of welfare: Social Democratic, Liberal-Anglo Saxon, Continental, Southern European, and Central and Eastern European (see Esping-Andersen, 1990; Ferrera, 1996; Bonoli, 1997; Katrougalos and Lazaridis, 2003; and the discussion in Gordon et al., 2006). ${ }^{10}$ To capture the exogenous forces driving pension systems' restructuring over time, we first show the results from the specifications in which we use the ratio of the number of births to the total population, lagged by 30 years, as an indicator of demographic pressures. ${ }^{11}$ Then, we consider a more general measure of common time-varying forces: a set

\footnotetext{
${ }^{10}$ Although this taxonomy of welfare models has been somewhat bypassed by reforms that have increased the correlation between contributions and benefits at the personal level everywhere, it is still considered to be a valid representation of the diversity in particular of the European pension system.

${ }^{11}$ The use of birth rates 30 years earlier as an instrument may be a problem if the age structure of the current population correlates with the voting preferences. According to the median voter theorem, preferences may change with age because of self-interest considerations. However,
} 
of time effects. To measure the age of the pension system, we consider the date on which social legislation on old-age insurance was introduced for the first time. Finally, we use a Maastricht Treaty dummy variable that takes the value one if a country signed the Maastricht Treaty and zero otherwise.

We instrument the pension reform variable, $P R E F$, which in the empirical model (1) is interacted with the level of financial literacy, $F L$, following Wooldridge (2010). We first estimate the predicted value of $P R E F$, which we name $P R E F$ hat, by running a regression that includes all the excluded instruments listed above and the set of control variables that will appear as included instruments in the second-stage regression. The predicted pension reform probability, PREFhat, and its interaction with FL, PREFhat $\times F L$, are then used as instruments for $P R E F$ and its interaction with financial literacy, $P R E F \times F L$, respectively. We cannot test the exclusion restriction because the second stage of the two-stage least-square linear model (2SLS) is just identified.

Our identification strategy is based on the assumption that the historical roots of welfare states and the common forces driving pension systems' changes over time are not significant determinants of the probability of re-electing a government at time $t$. We first present the results from the first-stage specification in which we consider an indicator of country-specific demographic pressures as a proxy for exogenous drivers of changes to the pension system. One advantage of using births rates 30 years ahead (BR) is the ability to report the results for

the impact of population aging on public expenditure remains an empirical question, because preferences depends on many other factors such as altruism, policy externalities, and voter turnout. Since empirical findings are mixed (for a literature review, see e.g. De Mello et al., 2014), we cannot rule this possibility completely. Thus, we show that the results are robust when we exclude this instrument and use time effects in our preferred IV specification. 
interactions between this time-varying variable and WS typologies easily in a table. The results are shown in column 2 of Table 2. They indicate that, with respect to the Social Democratic welfare state model, used as the reference group, the probability of implementing a pension reform is significantly lower in the Southern European welfare models and mildly lower in the Central and Eastern European models, and that these negative associations are less strong in countries with more positive demographic trends. The 2 SLS results in column 3 , in which BR is an excluded instrument, and in column 4, in which BR is an included instrument and appears among the explanatory variables for re-election probabilities in the 2SLS regression, confirm our main finding of a significant association between re-election probabilities and pension reforms and the role of FL in mediating it.

The weak identification test at the bottom of the third column of Table 3 is a Kleibergen-Paap F statistic that generalizes the Cragg-Donald F statistic in the presence of heteroskedasticity (see Baum et al., 2007). Following the "rule of thumb" by Staiger and Stock (1997), it should exceed 10 to exclude weak instruments. This is not the case when we use BR as a proxy for exogenous drivers of pension systems' reforms. Interestingly, this value is much higher than 10 in columns 5 and 6 that present estimates from the 2SLS regressions in which we interact the WS typology with the time effects. In column 5 , the time effects serve as excluded instruments, while in column 6 , they serve as included instruments. The empirical results from both the models confirm our finding that the electoral cost of a pension reform is positive across countries on average and that it decreases significantly in countries where the level of financial literacy is higher.

\subsection{Robustness checks}

In the following analyses, we test the robustness of our findings. As a baseline model, we consider the IV specification in column 6 of Table 2, which includes as explanatory variables 
in the second-stage regression all the macro-economic, demographic, and political control variables listed in column 3 of Table 1 and the year fixed effects. ${ }^{12}$

\section{Table 3 here}

As we discussed in Section 2, the probability of a government being elected for a second term of office may depend on several factors other than the ones that we have considered so far. In Table 3, we run a set of robustness checks on macroeconomic conditions. In column 1, we include the level of real GDP and its interaction with the pension reform variable (PREF) to control for the possibility that richer countries are more willing to undertake reforms. In the data, this seems not to be the case in column 1 or in column 2 , in which we control for the level of real GDP per capita and its interaction with $P R E F$.

Next, we consider two indicators of other potentially relevant macroeconomic conditions. In column 3, we include the unemployment rate, which may be a relevant element to the median voter when casting a ballot at national elections. In column 4 , we consider the current level of government debt to control whether voters are less likely to accept reforms that increase the government deficit at high levels of public debt, even when the reform is labelled as sustainable. We find that these variables are not significantly associated with re-election probabilities in our sample. Next, we check whether people with a longer time span left care more about long-term debt sustainability than older people, and thus whether the probability of a government being re-elected in the aftermath of a pension reform is higher in countries

\footnotetext{
${ }^{12}$ For each 2SLS model, we compute the predicted value of the pension reform variable from the corresponding first-stage regression (i.e. the one containing all the included instruments considered in our battery of robustness checks). We present the 2SLS estimates only for expositional convenience. Our findings hold when running OLS regressions (results available on request).
} 
where the median age is lower, by including an interaction term between $P R E F$ and median age. The estimates in column 5 of Table 3 confirm that the re-election probabilities are lower in younger societies, but there is no evidence that the age structure of the population affects the electoral outcomes through pensions.

Finally, in the last columns of Table 3, we explore whether people cast a ballot that is not only based on recent macroeconomic events, as we have assumed so far. In column 6 , we include the lagged values of changes in the level of economic activity, fiscal policy, and price dynamics (which account for the average of changes recorded two and three years before the election year). In column 7, we consider changes over a four-year time span of the legislature, which varies across countries due to the constitutional term of office of the elected chambers and in the case of early dissolution of the government. The lack of significance of changes in macroeconomic conditions over longer time spans is consistent with the findings of Fair (1978) and subsequent studies indicating that what matters most to voters is recent events.

\section{Table 4 here}

In Table 4, we focus on political conditioning factors. We start by presenting the results from the models in which we interact some political variables with $P R E F$ to determine whether the electoral costs of a pension reform differ due to the power of the government (in column 1), its political orientation (in column 2), or the level of political stability (in column 3). There is no evidence of such an indirect effect of political variables in our sample. We also test whether the re-election probabilities depend on the political support from other parties that the government may enjoy during the legislature. The results in column 4 of Table 4 indicate that the polarization variable, which measures the political distance between the leading party and the largest opposition party, is not associated with our dependent variable per se or when it is interacted with the pension reform variable. In column 5, we consider whether the old-age dependency ratios are expected to increase over a 30-year horizon, and we interact the 
difference between their projections and their current level (which we refer to as "change ODR") with the PREF variable to ascertain whether the perceived need to reform among the electorate matters to the electoral cost of a pension reform. We also control for the possibility that this effect is less relevant in countries where the pension system is more similar to an FF system than to a PAYG one. The FF variable takes the value one in Canada, the Netherlands, the UK, and France and zero elsewhere. The results indicate that the probability of a government being re-elected is lower in countries where the old-age dependency ratios are expected to increase more, that is, in faster-ageing societies. The interaction terms are instead not significant. In our data, there is no evidence that the electoral costs of a pension reform depend on the perceived need to reform or on the type of pension system. In column 6, we consider whether re-election probabilities depend on the maximum number of years for which a head of the government has been in office to test whether the re-election probabilities are higher in countries where there is a greater tradition of re-electing the incumbent head of the government. In the same column, we include a dummy variable that takes the value one if the government enacted the pension reform in the first two years of office to determine whether the electoral cost of a reform is lower in countries that enacted it early in the legislature. In the data, both these variables are not significantly associated with re-election probabilities. Finally, we use a different definition of re-election. In column 7 of Table 4, a government is re-elected if the party to which the incumbent head of the government belongs is still able to appoint her successor, independently of her identity. As the results show, our main findings also hold when we use this alternative dependent variable.

\subsection{Financial literacy and other education indicators}

The above analysis shows that FL helps to explain the association between electoral outcomes and pension reforms. In Table 5, we show that our results are robust to alternative functions of the FL variable, and we consider other dimensions of education. 
So far, we have used the four-year moving average of the IMD World Competitiveness Yearbook's indicator to measure the level of FL among the population. This timing allows us to reduce the measurement errors and consider the level of FL not only in the election year but also over the years during which the head of a government is likely to have ruled the country and enacted policies. In the first column of Table 5, we show that our findings are robust to the use of the average level of FL over the election year and the year preceding it. Our results also hold when we use the yearly value of FL, that is, when we consider its level in the election year (in column 2), and when we restrict the sample to consider the 1995-2008 period for which yearly values on FL are compiled and published in the IMD World Competitiveness Yearbook (in column 3).

Another robustness check that may help to strengthen our conclusion that the empirical findings are driven by financial literacy is to show that the results do not rely on the specific FL indicator that we have used so far. Let us consider the OECD-PISA financial literacy score (OECD, 2017). This indicator, which assesses 15-year-old students' experience with and knowledge about money, is available for a limited number of countries. The 2015 assessment covers 15 countries and economies, 7 of which are countries, or regions of a country, that belong to our sample, namely the Flemish Community of Belgium, 7 Canadian provinces, Italy, the Netherlands, Poland, the Slovak Republic, and Spain. ${ }^{13}$ If we use these observations to run

${ }^{13}$ Data on average financial literacy performance were also collected in 2012, when 18 countries participated in an optional assessment by the PISA on financial literacy. However, the 2012 score is available only for four countries or regions of a country belonging to our sample (see Table IV.3.1 of the PISA 2015 Report). Given the limited value added of these data, we prefer to use the 2015 score only and exploit its cross-sectional information. 
regressions on a 7-country sample, assuming that the OECD-PISA score in financial literacy does not change over time, we obtain the results reported in column 4 . The sample is very small, and the results should be read only as preliminary and suggestive evidence of the goodness of the IMD World Competitiveness Yearbook's indicator that we have used so far in capturing the dimension of education that we call "financial literacy".

Finally, we consider people's achievements in other dimensions of education. We use other indicators of human capital, such as the OECD-PISA score on mathematical performance, and attainment in secondary and tertiary schools. Table A.4 shows the correlations between the FL and these indicators of education. The bivariate correlations between the FL, the PISA score in mathematical performance, and the tertiary schooling are high. Countries with a higher percentage of highly educated people are countries where students perform better in mathematics and have higher levels of FL. Secondary schooling, instead, is less positively associated with the other indicators of education. In columns 5 to 7 of Table 5, we report the estimates from the empirical models in which we use in the place of FL the indicators of education that we have just presented, one by one to avoid incurring multicollinearity issues. Interestingly, these measures are not significant determinants of the association between reforms and re-election probabilities.

In our data, only financial literacy reduces the electoral cost of pension reforms. These findings support our view that the knowledge of basic economic and financial concepts has distinctive features that other dimensions of education do not capture. FL is a specific form of human capital that helps people to understand reforms that have relevant economic content and a significant impact on the life cycle of individuals. 


\section{Conclusion}

Our study of legislative elections held between 1990 and 2010 in advanced countries provides evidence in favour of a role of economic and financial knowledge in changing the probability of the head of the government being re-elected in the aftermath of a major pension reform. Where FL is higher, economic reforms that impose current sacrifices in exchange for future benefits seem to be understood better by citizens who are thus less likely to "punish" the governments that introduced them. The "electoral cost" of reforms is therefore lower.

Our results for the specific case of pension reforms are robust with respect to the inclusion of indicators that account for the characteristics of the political system and for political, demographic, and macro-economic conditions. Interestingly, they do not hold when more general indicators of school attainment are used. Future research might successfully extend our analysis by collecting information on other reforms belonging to the same policy package or approved during the same legislature, such as policy innovations in the labour, real, and financial markets. It would also be interesting to use other indicators of economic and financial knowledge, like the PISA score of financial literacy and measures collected in national surveys that are made comparable across countries, as soon as more data become available.

Our estimates suggest that the electoral gains from investing in financial literacy are sizeable. For a country with the average value of FL in our sample, enacting a pension reform changes the probability of the head of the government being re-elected by 15 percentage points. The costs of investing in financial literacy, on the other hand, are relatively small compared with other public policies. Financial literacy can be included in compulsory education curricula, and many countries are developing national strategies that include adult financial literacy programmes meant to increase financial inclusion and complement consumers' protection (OECD, 2015). 
Providing formal financial education in schools and to targeted adult audiences is becoming an important area of intervention, because the costs of financial illiteracy are high. Understanding basic economic and financial concepts is a key skill for individual consumers and investors who need to take proper decisions to manage their economic resources over their life cycle and who participate in fast-evolving financial markets. Our work suggests that financial illiteracy may also harm reformist efforts and has clear policy implications. As implied by Mr Juncker's aphorism quoted in the introduction, the awareness of what is involved in a reform could be an important determinant of its electoral cost and future viability. Of course, FL is not a sufficient condition for the success of reforms per se. Illiteracy can, conversely, thwart their effectiveness by calling for an excessively long phase-in period or backwards changes to previously approved reforms. In this respect, FL could become a new, more transparent alternative to concealing the unpleasant consequences of reforms from citizens, a potentially key element in the relationship between citizens and politicians. Since such literacy is primarily a result of education, the government policy could thus indirectly induce long-run support for virtuous reforms and more effective citizenship by promoting specific education programmes for adults in parallel with basic financial education in schools. 


\section{References}

Alesina, Alberto, Silvia Ardagna, and Francesco Trebbi (2006). Who Adjusts and When? The Political Economy of Reforms. IMF Staff Papers 53: 1-29.

Alesina, Alberto, Dorian Carloni, and Giampaolo Lecce (2013). The Electoral Consequences of Large Fiscal Adjustments. In Alberto Alesina and Francesco Giavazzi (eds.), Fiscal Policy after the Financial Crisis. NBER: University of Chicago Press, 531-570.

Angrist, Joshua D., and Jörn-Steffen Pischke (2009). Mostly Harmless Econometrics. New Jersey: Princeton University Press.

Barro, Robert, and Jong-Wha Lee (2013). A New Data Set of Educational Attainment in the World, 1950-2010. Journal of Development Economics 104: 184-198.

Baum, Christopher F., Mark E. Schaffer, and Steven Stillman (2007). Enhanced Routines for Instrumental Variables/GMM Estimation and Testing. Boston College Economics Working Paper No. 667.

Beck, Thorsten, George Clarke, Alberto Groff, Philip Keefer, and Patrick Walsh (2001). New Tools in Comparative Political Economy: The Database of Political Institutions. World Bank Economic Review 15(1): 165-176.

Bonfiglioli, Alessandra, and Gino Gancia (2016). Economic Uncertainty and Structural Reforms. Universitat Pompeu Fabra Economics Working Paper No. 1494.

Bonoli, Giuliano (1997). Classifying Welfare States: A Two-Dimension Approach. Journal of Social Policy 26(3): 351-372.

Brender, Adi, and Allan Drazen (2008). How Do Budget Deficits and Economic Growth Affect Reelection Prospects? Evidence from a Large Panel of Countries. American Economic Review 98(5): 2203-2220. 
Bucher-Koenen, Tabea, and Annamaria Lusardi (2011). Financial literacy and retirement planning in Germany. Journal of Pension Economics and Finance 10(4): 565-584.

Buti, Marco, Alessandro Turrini, Paul Van den Noord, and Pietro Biroli (2010). Reforms and Re-elections in OECD Countries. Economic Policy 25(1): 61-116.

Chong, Dennis, and James N. Druckman (2007). Framing theory. Annual Review of Political Science 10: 103-126.

Cruz, Cesi, Philip Keefer, and Carlos Scartascini (2016). Database of Political Institutions Codebook, 2015 Update (DPI2015). Inter-American Development Bank.

De Mello, Luiz, Simone Schotte, Erwin Tiongson, and Hernan Winkler (2014). Political Economy Issues in Aging Societies of Europe and Central Asia. Background paper for Golden Aging, World Bank, Washington, DC.

Dias da Silva, Antonio, Audrey Givone, and David Sondermann (2017). When Do Countries Implement Structural Reforms? ECB Working Paper 2078.

Duval, Romain (2008). Is There a Role for Macroeconomic Policy in Fostering Structural Reforms? Panel Evidence from OECD Countries over the Past Two Decades. European Journal of Political Economy 24(2): 491-502.

Esping-Andersen, Gosta (1990). Three Worlds of Welfare Capitalism. Cambridge: Polity Press. Fair, Ray C. (1978). The Effect of Economic Events on Votes for President. Review of Economics and Statistics 60(2): 159-173.

Ferrera, Maurizio (1996). The "Southern Model" of Welfare in Social Europe. Journal of European Social Policy 6(1): 17-37.

Fontoura Gouveia, Ana (2017). Political Support for Reforms of the Pension System: Two Experiments. Journal of Pensions and Finance 16(3): 371-394. 
Fornero, Elsa, and Chiara Monticone (2011). Financial Literacy and Pension Plan Participation in Italy. Journal of Pension Economics and Finance 10: 547-564.

Giofré, Maela (2017). Financial Education, Investor Protection and International Portfolio Diversification. Journal of International Money and Finance 71: 111-139.

Glenn, Norval D., and Michael Grimes (1968). Aging, Voting, and Political Interest. American Sociological Review 35(4): 563-575.

Gordon L. Clark, Alicia H. Munnell, and J. Michael Orszag (2006). The Oxford Handbook of Pensions and Retirement Income: Volume 13. Oxford: Oxford University Press.

Luigi Guiso \& Tullio Jappelli, 2009. "Financial Literacy and Portfolio Diversification," CSEF Working Papers 212, Centre for Studies in Economics and Finance (CSEF), University of Naples, Italy.

Jappelli, Tullio (2010). Economic Literacy: An International Comparison. Economic Journal 120: F429-F451.

Katrougalos, George, and Gabriella Lazaridis (2003). Southern European Welfare States: Problems, Challenges and Prospects. New York: Palgrave Macmillan.

Lo Prete, Anna (2013). Economic Literacy, Inequality, and Financial Development. Economics Letters 118(1): 74-76.

Lo Prete, Anna (2018). Inequality and the Finance You Know: Does Economic Literacy Matter? Economa Politica 35(1): 183-205.

Lusardi, Annamaria, and Olivia Mitchell (2007). Baby Boomer Retirement Security: The Roles of Planning, Financial Literacy, and Housing Wealth. Journal of Monetary Economics 54(1): 205-224.

Lusardi, Annamaria, and Olivia S. Mitchell (2014). The Economic Importance of Financial Literacy: Theory and Evidence. Journal of Economic Literature 52(1): 5-44. 
Montagnoli, Alberto, Mirko Moro, Georgios A. Panos, and Robert E. Wright (2017). Financial Literacy and Attitudes to Redistribution. Business School - Economics, University of Glasgow Working Paper No. 2017_03.

OECD (2015). National Strategies for Financial Education: OECD/INFE Policy Handbook. OECD (2016). Mathematics Performance (PISA) (Indicator). Online database.

OECD (2017). PISA 2015 Results (Vol. IV): Students' Financial Literacy.

Prati, Alessandro, Massimiliano G. Onorato, and Chris Papageorgiou (2013). Which Reforms Work and under What Institutional Environment? Evidence from a New Data Set on Structural Reforms. Review of Economics and Statistics 95(3): 946-968.

Staiger, Douglas, and James H. Stock (1997). Instrumental variables regression with weak instruments. Econometrica 65(3): 557-586.

Van Rooij, Marteen, Annamaria Lusardi, and Rob Alessie (2011). Financial Literacy and Stock Market Participation. Journal of Financial Economics 101: 449-472.

Wooldridge, Jeffrey M. (2010). Econometric Analysis of Cross Section and Panel Data, Second Edition. Cambridge: MIT Press. 


\section{Data Appendix}

The data set includes information for the 21 OECD countries listed in Table A.1. We collected data on parliamentary elections held between 1990 and 2010, ruling out presidential elections in countries where they take place, and on major pension reforms that were signed into law in the years before the parliamentary elections took place.

Pension reforms. A list of reform events is available in Table A.2. Details of the pension reform variable are available in the Online Appendix to this paper.

FL and other indicators of education. The indicator of financial literacy (FL) is the measure of "economic literacy among the population" compiled by the IMD Business School in Lausanne. Using data from international databases and from an international survey of expert managers, the IMD Business School publishes yearly indicators of the competitiveness of countries (i.e. their economic performance, government efficiency, business efficiency, and infrastructure) in its IMD World Competitiveness Yearbook. Data on FL are available for 55 countries over the 1995-2008 period. The OECD-PISA score in FL measures the average financial literacy performance in 2015 (PISA, 2017). The OECD-PISA score in mathematics is the average value of the PISA scores in mathematical performance for boys and girls (we include the simple average over gender). They are available for 2003, 2006, 2009, and 2012 (OECD, 2016). The measures of secondary and tertiary general school attainment are from the Barro-Lee Educational Attainment Dataset (version 2.0, June 2014 release; see Barro and Lee, 2013). They are recorded every five years from 1950 to 2010. In the empirical models, we use the four-year moving average of the indicators of education. Missing data are interpolated when two consecutive observations are available. The FL indicator is filled onwards/backwards by keeping the first/last value constant in the years with no record.

Control variables. The macro-economic variables are drawn from the Penn World Table (version 9.0), the OECD, and the IMF World Economic Outlook database. The data on 
the median age of the total population (years) are drawn from the UN World Population Prospects (2015 revision). The data on the characteristics of the political system and on political conditions are from the Database of Political Institutions 2015 described by Cruz et al. (2016), which is an updated version of Beck et al.'s (2001) original database. The demographic projections refer to old-age dependency ratios (i.e. the ratio of people older than 64 to the working-age population) from the online database Health Nutrition and Population Statistics: Population Estimates and Projections by the World Bank.

Instrumental variables. We consider five welfare state (WS) typologies: Social Democratic, Liberal, Continental, Southern European, and Central and Eastern European. The age of the pension system is measured with respect to the year of introduction of the principal legislation on old-age insurance. We collect information on models and history of welfare states from several sources (Esping-Andersen, 1990; Ferrera, 1996; Bonoli, 1997; Katrougalos and Lazaridis, 2002; Gordon et al., 2006). The data on birth rates are from the World Bank online database and are expressed in terms of annual births per 1000 population. 
Table A.1. Elections and pension reforms in 1990-2010, by country.

\begin{tabular}{lcc}
\hline \hline Country & $\begin{array}{c}\text { No. of legislative elections } \\
\text { in the sample }\end{array}$ & $\begin{array}{c}\text { No. of major pension } \\
\text { reforms in the previous } \\
\text { legislature }\end{array}$ \\
\hline Austria & 7 & 1 \\
Belgium & 6 & 1 \\
Canada & 6 & 1 \\
Czech Republic & 6 & 1 \\
Denmark & 6 & 0 \\
Finland & 5 & 2 \\
France & 4 & 2 \\
Germany & 6 & 3 \\
Greece & 7 & 0 \\
Hungary & 5 & 1 \\
Ireland & 4 & 0 \\
Italy & 6 & 3 \\
Japan & 7 & 2 \\
Netherlands & 6 & 2 \\
Norway & 5 & 1 \\
Poland & 5 & 1 \\
Portugal & 6 & 2 \\
Slovak Republic & 5 & 1 \\
Spain & 5 & 1 \\
Sweden & 6 & 2 \\
United Kingdom & 5 & 1 \\
\hline \hline
\end{tabular}


Table A.2. 1990-2010 elections and major pension reforms, by country.

\begin{tabular}{|c|c|c|}
\hline Country & $\begin{array}{l}\text { Year of } \\
\text { election }\end{array}$ & Major pension reforms signed into law before the election day \\
\hline Austria & 2006 & $\begin{array}{l}\text { Austrian Pension Reform (2003), Harmonization of Austrian Pension } \\
\text { Systems Act (2004) }\end{array}$ \\
\hline Belgium & 1999 & Framework Act (1996) \\
\hline Canada & 2000 & Canada Pension Plan Reform (1998) \\
\hline Czech Republic & 1996 & Pension Reform (1995) \\
\hline Finland & 1999 & Pension Reform Law (HE 189/1996) \\
\hline Finland & 2007 & $\begin{array}{l}\text { Pension Reform Laws on Earnings-Related Pensions (HE 118/2005) } \\
\text { and on National Pensions (HE 119/2005) }\end{array}$ \\
\hline France & 1993 & Balladur Reform (1993) \\
\hline France & 2007 & Pension Reform Act (2003) \\
\hline Germany & 1994 & Pension Reform Act (1992) \\
\hline Germany & 2002 & Riester Reform (2001) \\
\hline Germany & 2009 & Retirement Age Adjustment Act (2007) \\
\hline Hungary & 1998 & $\begin{array}{l}\text { Pension Reform Acts LXXX on Eligibilities and Finances of Social } \\
\text { Insurance and Private Pension (1997), LXXXI on Social Security } \\
\text { Pensions (1997), LXXXII on Private Pensions and Private Pension } \\
\text { Funds (1997) }\end{array}$ \\
\hline Italy & 1994 & Amato Reform (1992) \\
\hline Italy & 1996 & Dini Reform (1995) \\
\hline Italy & 2006 & Maroni Reform (2004) \\
\hline Japan & 2000 & Pension System Reform (2000) \\
\hline Japan & 2005 & Pension System Reform (2004) \\
\hline Netherlands & 1998 & Privatization of the Public Pension Fund ABP (1996) \\
\hline Netherlands & 2006 & Life Course Savings Scheme (2006) \\
\hline Norway & 2009 & Flexible Retirement Act (2009) \\
\hline Poland & 2001 & $\begin{array}{l}\text { Pension Reform (1999), Act No. } 887 \text { on the Social Insurance System } \\
\text { (1998), Act No. } 162 \text { on Old-Age and Disability Pensions from the } \\
\text { Social Insurance Fund (1998) }\end{array}$ \\
\hline Portugal & 1995 & Law 329/93 (1993) \\
\hline Portugal & 2005 & Law $60-B / 2005(2005)$ \\
\hline Slovak Republic & 2006 & $\begin{array}{l}\text { Social Insurance Act (2003), Old-Age Pension Savings Act (2004), } \\
\text { Supplementary Old-Age Pension Savings Act (2004) }\end{array}$ \\
\hline Spain & 2000 & Royal Decree 6/1997 (1997) \\
\hline Sweden & 1998 & Pension Reform (1998) \\
\hline Sweden & 2010 & Reform of the ITP Occupational Pension Plan (2007) \\
\hline United Kingdom & 2010 & Pensions Act (2007) \\
\hline
\end{tabular}

Note: According to our coding, three countries recorded no major pension reforms over the period under analysis, namely: Denmark, Greece, and Ireland. A description of the characteristics of these reform events and comments by international organizations are available in the Online Appendix to this paper. 
Table A.3. Summary statistics.

\begin{tabular}{lrrrrr}
\hline \hline Variable & Obs. & Mean & Std Dev. & Min. & Max. \\
\hline Pension reform & 118 & 0.24 & 0.43 & 0.00 & 1.00 \\
Re-election of the head of the & 118 & 0.42 & 0.49 & 0.00 & 1.00 \\
government & & & & & \\
Re-election, head gov. from same party & 118 & 0.47 & 0.50 & 0.00 & 1.00 \\
Output gap & 109 & -0.01 & 2.91 & -7.58 & 8.94 \\
Change in output gap & 107 & 2.21 & 4.52 & -5.34 & 35.84 \\
Change in gov. bal. & 107 & 2.58 & 5.25 & -7.27 & 47.73 \\
Change in inflation & 115 & 3.80 & 5.07 & -0.57 & 41.10 \\
Real GDP level & 118 & 884 & 1083 & 64 & 4414 \\
Real GDP per capita level & 118 & 29.29 & 10.63 & 8.38 & 76.02 \\
Unemployment rate & 109 & 8.23 & 4.02 & 2.35 & 22.80 \\
Government debt & 113 & 57.80 & 31.98 & 9.66 & 182.16 \\
Median age of the population & 118 & 38.06 & 2.56 & 29.02 & 44.52 \\
Birth rate, lagged 30 years & 118 & 16.54 & 3.01 & 9.90 & 24.60 \\
Change in old-age dependency ratios & 118 & 17.33 & 6.14 & 3.37 & 31.14 \\
Age of the pension system & 118 & 83.12 & 17.39 & 48 & 120 \\
Proportional & 118 & 0.87 & 0.33 & 0.00 & 1.00 \\
Presidential & 118 & 0.36 & 0.48 & 0.00 & 1.00 \\
Constitutional tenure & 118 & 4.26 & 0.44 & 4.00 & 5.00 \\
Margin of majority & 118 & 0.55 & 0.09 & 0.25 & 0.86 \\
Left-oriented & 118 & 0.47 & 0.50 & 0.00 & 1.00 \\
Stability & 118 & 0.05 & 0.14 & 0.00 & 0.75 \\
Polarization & 114 & 1.19 & 0.93 & 0.00 & 2.00 \\
Maximin years of office & 118 & 8.27 & 3.01 & 4.00 & 16.00 \\
Beginning of the legislature & 118 & 0.15 & 0.36 & 0.00 & 1.00 \\
FL & 118 & 5.33 & 1.26 & 2.84 & 7.96 \\
FL averaged over t and t-1 & 118 & 5.33 & 1.28 & 2.88 & 8.00 \\
FL yearly value & 118 & 5.30 & 1.31 & 2.58 & 8.16 \\
OECD-PISA score in FL & 39 & 497.21 & 32.28 & 445.00 & 541.00 \\
OECD-PISA score in mathematics & 64 & 502.20 & 24.20 & 445.50 & 546.83 \\
Secondary schooling & 118 & 54.41 & 12.91 & 21.23 & 88.00 \\
Tertiary schooling & 118 & 17.50 & 6.86 & 4.87 & 41.22 \\
\hline \hline
\end{tabular}

Notes: This table shows descriptive statistics for the variables used in the analysis. 
Table A.4. Correlations between FL and other education indicators.

\begin{tabular}{l|llll}
\hline \hline & FL & $\begin{array}{c}\text { PISA score in } \\
\text { maths }\end{array}$ & $\begin{array}{l}\text { Secondary } \\
\text { schooling }\end{array}$ & $\begin{array}{c}\text { Tertiary } \\
\text { schooling }\end{array}$ \\
\hline FL & 1 & & & \\
PISA score in maths & $0.71^{* * *}$ & 1 & & \\
Secondary schooling & 0.04 & 0.06 & 1 & 1 \\
Tertiary schooling & $0.65^{* * *}$ & $0.53^{* *}$ & -0.30 & 1 \\
\hline \hline
\end{tabular}

Notes: $(*),(* *)$, and $(* * *)$ denote significance at the (10), (5), and (1) per cent level. The data refer to pairwise correlations between the indicators using their 2008 value. 
Figure 1. Pension reforms and re-election frequencies.

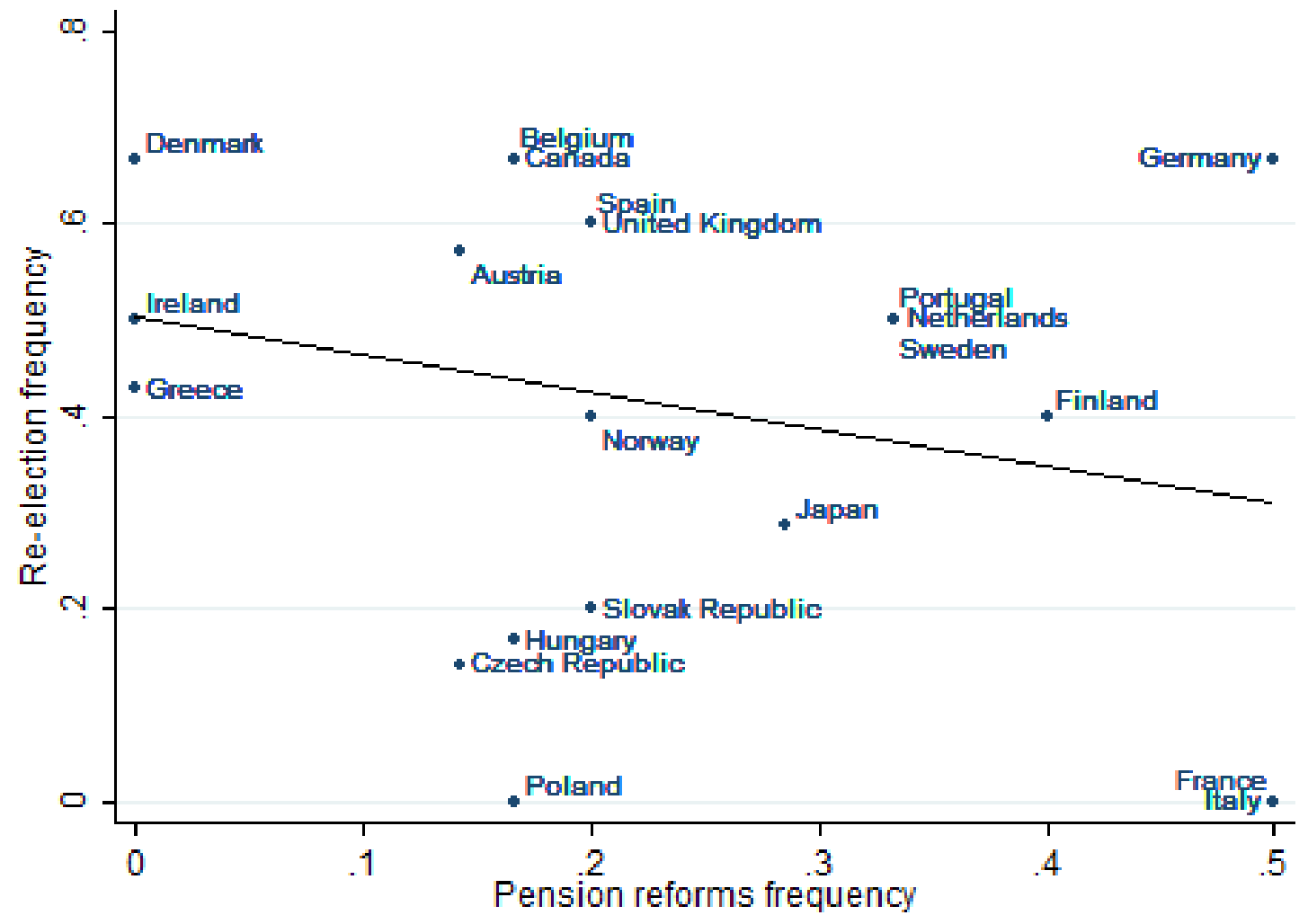

Notes: The panel plots the number of re-election events against the number of major pension reform episodes in each country, both weighted by the number of election events over the 1990-2010 period. The correlation from an OLS regression, represented by the fit line, is negative (coefficient -0.39) and significant (t-statistic -2.89). 
Figure 2. Level of financial literacy across countries in 2008.

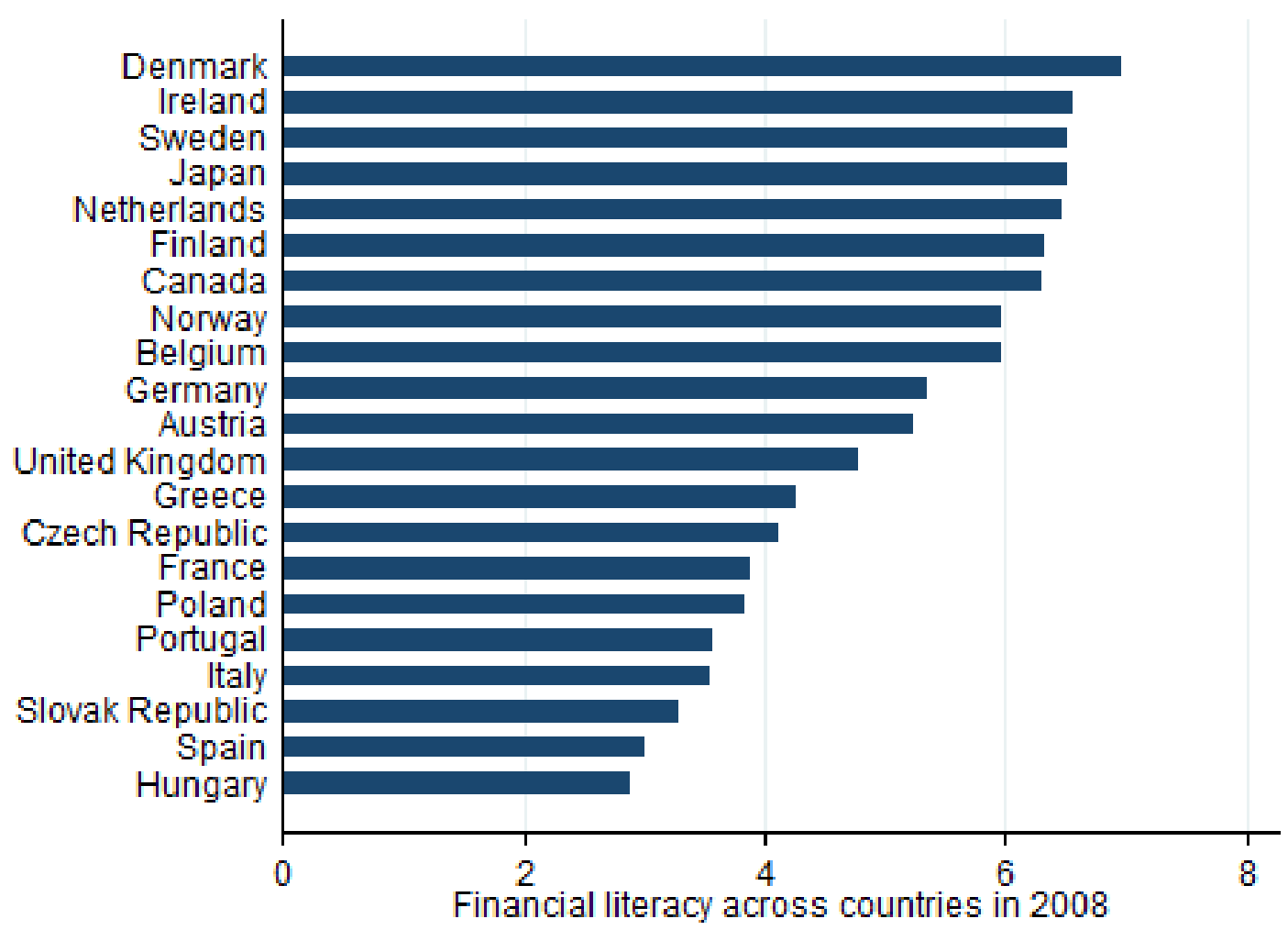


Figure 3. Level of financial literacy in 1995 and in 2008, by country.

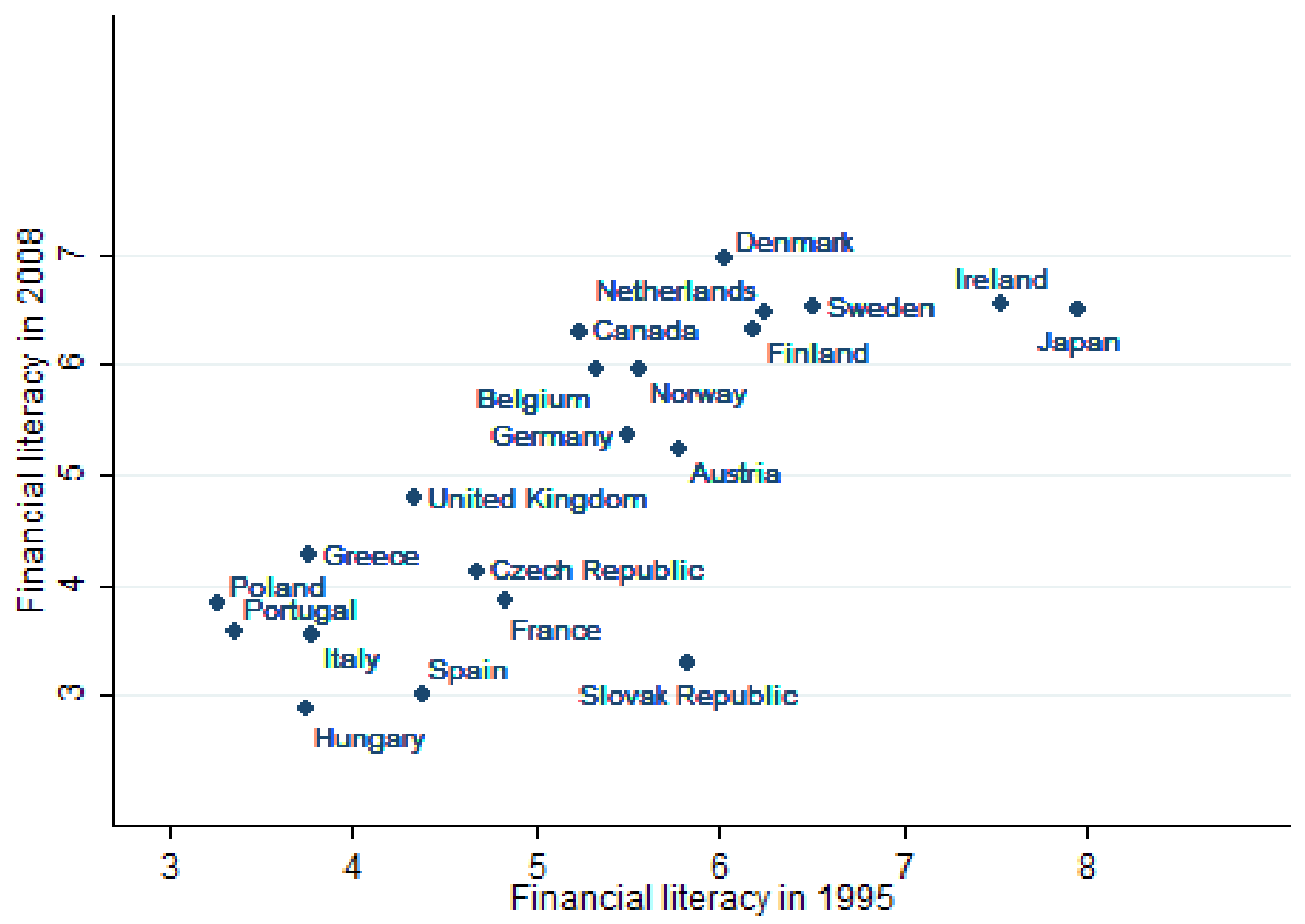


Table 1. Reforms, financial literacy, and re-election.

\begin{tabular}{|c|c|c|c|c|c|c|c|}
\hline \multirow{2}{*}{$\begin{array}{l}\text { Dependent variable: } \\
\text { Estimator: }\end{array}$} & \multicolumn{7}{|c|}{ Re-election of the head of the government } \\
\hline & OLS & OLS & OLS & OLS & LSDV & LSDV & PROBIT \\
\hline & $(1)$ & $(2)$ & $(3)$ & $(4)$ & $(5)$ & $(6)$ & $(7)$ \\
\hline \multirow[t]{2}{*}{ PREF } & 0.111 & $-1.266 * * *$ & $-1.173 * * *$ & $-1.279 * *$ & $-1.181 * *$ & $-1.404 * *$ & $-1.561 * * *$ \\
\hline & $(0.108)$ & $(0.331)$ & $(0.421)$ & $(0.490)$ & $(0.446)$ & $(0.628)$ & $(0.5133)$ \\
\hline \multirow[t]{2}{*}{ PREF*FL } & & $0.265 * * *$ & $0.252 * * *$ & $0.290 * * *$ & $0.258 * * *$ & $0.326 * * *$ & $0.313 * * *$ \\
\hline & & $(0.067)$ & $(0.080)$ & $(0.089)$ & $(0.078)$ & $(0.101)$ & $(0.099)$ \\
\hline \multirow[t]{2}{*}{ FL } & & 0.009 & -0.008 & -0.062 & -0.063 & -0.100 & -0.002 \\
\hline & & $(0.040)$ & $(0.049)$ & $(0.048)$ & $(0.116)$ & $(0.121)$ & $(0.039)$ \\
\hline \multirow[t]{2}{*}{ Output gap } & & & $0.039 * *$ & 0.035 & 0.028 & 0.034 & $0.037 * * *$ \\
\hline & & & $(0.017)$ & $(0.026)$ & $(0.022)$ & $(0.035)$ & $(0.014)$ \\
\hline \multirow[t]{2}{*}{ Change in output gap } & & & -0.008 & -0.002 & -0.008 & -0.003 & -0.011 \\
\hline & & & $(0.009)$ & $(0.008)$ & $(0.006)$ & $(0.009)$ & $(0.014)$ \\
\hline \multirow[t]{2}{*}{ Change in gov. bal. } & & & 0.007 & 0.005 & $0.010 *$ & 0.009 & 0.011 \\
\hline & & & $(0.006)$ & $(0.008)$ & $(0.005)$ & $(0.009)$ & $(0.010)$ \\
\hline \multirow[t]{2}{*}{ Change in inflation } & & & -0.016 & -0.034 & -0.001 & -0.039 & -0.012 \\
\hline & & & $(0.023)$ & $(0.022)$ & $(0.028)$ & $(0.031)$ & $(0.020)$ \\
\hline \multirow[t]{2}{*}{ Median age } & & & $-0.048 * *$ & $-0.096 * * *$ & -0.018 & 0.007 & $-0.047 * *$ \\
\hline & & & $(0.023)$ & $(0.031)$ & $(0.033)$ & $(0.099)$ & $(0.020)$ \\
\hline \multirow[t]{2}{*}{ Proportional } & & & -0.141 & -0.206 & & & -0.187 \\
\hline & & & $(0.173)$ & $(0.200)$ & & & $(0.149)$ \\
\hline \multirow[t]{2}{*}{ Presidential } & & & $-0.265^{* *}$ & $-0.433 * * *$ & & & $-0.241 * *$ \\
\hline & & & $(0.110)$ & $(0.131)$ & & & $(0.098)$ \\
\hline \multirow[t]{2}{*}{ Consitut. tenure } & & & $-0.246^{*}$ & -0.243 & & & $-0.269 * *$ \\
\hline & & & $(0.134)$ & $(0.158)$ & & & $(0.122)$ \\
\hline \multirow[t]{2}{*}{ Margin of majority } & & & 0.852 & 0.895 & 1.095 & $1.531^{*}$ & $0.750 *$ \\
\hline & & & $(0.519)$ & $(0.563)$ & $(0.639)$ & $(0.855)$ & $(0.423)$ \\
\hline \multirow[t]{2}{*}{ Left-oriented } & & & 0.010 & 0.065 & 0.012 & 0.008 & 0.015 \\
\hline & & & $(0.099)$ & $(0.114)$ & $(0.077)$ & $(0.110)$ & $(0.083)$ \\
\hline \multirow[t]{2}{*}{ Stability } & & & $-0.798 * * *$ & $-0.744 * * *$ & $-0.878 * * *$ & $-0.813 * *$ & $-1.165 * *$ \\
\hline & & & $(0.296)$ & $(0.369)$ & $(0.296)$ & $(0.326)$ & $(0.476)$ \\
\hline Country effects & & & & & $\mathrm{X}$ & $\mathrm{X}$ & \\
\hline Time effects & & & & $\mathrm{X}$ & & $X$ & \\
\hline Observations & 118 & 118 & 107 & 107 & 107 & 107 & 107 \\
\hline
\end{tabular}

Notes: Robust standard errors in parentheses. $(*),(* *)$, and $(* * *)$ denote significance at the (10), (5), and (1) per cent level. All the specifications include a constant, which is not reported. The OLS estimates are in columns 1,2,3, and 4. The LSDV estimates are in columns 5 and 6 . The Probit average marginal effects are in column 7.

Source: See the Data Appendix. 
Table 2. Endogeneity of pension reforms.

\begin{tabular}{|c|c|c|c|c|c|c|}
\hline Dependent variable: & Re-el & PREF & Re-el & Re-el & Re-el & Re-el \\
\hline Estimator: & OLS & OLS & 2SLS & 2 SLS & 2SLS & 2 SLS \\
\hline & $(1)$ & (2) & $(3)$ & (4) & $(5)$ & $(6)$ \\
\hline PREF & $\begin{array}{l}-0.989 * * \\
(0.449)\end{array}$ & & $\begin{array}{l}-3.042^{* * *} \\
(1.278)\end{array}$ & $\begin{array}{l}-3.033 * * \\
(1.267)\end{array}$ & $\begin{array}{l}-0.965^{* *} \\
(0.451)\end{array}$ & $\begin{array}{l}-1.043^{* *} \\
(0.462)\end{array}$ \\
\hline PREF*FL & $\begin{array}{l}0.226 * * * \\
(0.084)\end{array}$ & & $\begin{array}{l}0.593 * * \\
(0.256)\end{array}$ & $\begin{array}{l}0.592 * * \\
(0.254)\end{array}$ & $\begin{array}{l}0.213 * * \\
(0.090)\end{array}$ & $\begin{array}{l}0.258 * * * \\
(0.090)\end{array}$ \\
\hline FL & $\begin{array}{l}0.065 \\
(0.061)\end{array}$ & & $\begin{array}{l}-0.076 \\
(0.063)\end{array}$ & $\begin{array}{l}-0.078 \\
(0.072)\end{array}$ & $\begin{array}{l}-0.001 \\
(0.046)\end{array}$ & $\begin{array}{l}-0.057 \\
(0.039)\end{array}$ \\
\hline Liberal WS & & $\begin{array}{l}-1.352 \\
(1.038)\end{array}$ & & & & \\
\hline Continental WS & & $\begin{array}{l}-0.973 \\
(0.947)\end{array}$ & & & & \\
\hline Southern European WS & & $\begin{array}{l}-1.907 * \\
(0.966)\end{array}$ & & & & \\
\hline Central-Eastern European WS & & $\begin{array}{l}-2.238 \\
(1.380)\end{array}$ & & & & \\
\hline Birth rate 30 years ahead (BR) & & $\begin{array}{l}-0.070 \\
(0.060)\end{array}$ & & $\begin{array}{l}-0.003 \\
(0.031)\end{array}$ & & \\
\hline BR*Liberal WS & & $\begin{array}{l}0.086 \\
(0.063)\end{array}$ & & & & \\
\hline BR*Continental WS & & $\begin{array}{l}0.071 \\
(0.063)\end{array}$ & & & & \\
\hline BR*Southern European WS & & $\begin{array}{l}0.111^{*} \\
(0.059)\end{array}$ & & & & \\
\hline BR*Central-Eastern European WS & & $\begin{array}{l}0.140 \\
(0.085)\end{array}$ & & & & \\
\hline Maastricht Treaty & & $\begin{array}{l}0.087 \\
(0.131)\end{array}$ & & & & \\
\hline Age of the pension system & & $\begin{array}{l}-0.003 \\
(0.004)\end{array}$ & & & & \\
\hline Time effects & & & & & & $\mathrm{X}$ \\
\hline $\begin{array}{l}\text { Kleibergen-Paap weak } \\
\text { identification F statistic }\end{array}$ & & & 7.36 & 7.77 & 24.29 & 25.52 \\
\hline Observations & 75 & 107 & 107 & 107 & 107 & 107 \\
\hline
\end{tabular}

Notes: Robust standard errors in parentheses. $(*),(* *)$, and $(* * *)$ denote significance at the $(10),(5)$, and (1) per cent level. All the specifications include controls for macroeconomic, demographic, and political conditions and a constant, not reported. The OLS estimates are in columns 1 and 2. The 2SLS estimates are in columns 3-6. The set of excluded instruments includes the age of the pension system, a Maastricht Treaty dummy, welfare state dummies, and their interactions with exogenous time-varying forces driving pension systems' change (proxied by the birth rate 30 years ahead in columns 3 and 4 and by time effects in columns 5 and 6). In the 2SLS regressions, the variable PREF and its interaction with FL are instrumented using the predicted value of PREF and its interaction with FL from the corresponding first-stage models.

Source: See the Data Appendix. 
Table 3. Robustness checks - macroeconomic conditioning factors.

\begin{tabular}{|c|c|c|c|c|c|c|c|}
\hline \multirow{2}{*}{$\begin{array}{l}\text { Dependent variable: } \\
\text { Estimator: }\end{array}$} & \multicolumn{7}{|c|}{ Re-election of the head of the government } \\
\hline & 2SLS & 2SLS & 2SLS & 2SLS & 2SLS & 2SLS & 2SLS \\
\hline & $(1)$ & $(2)$ & $(3)$ & $(4)$ & $(5)$ & $(6)$ & $(7)$ \\
\hline PREF & $\begin{array}{l}-1.059 * * \\
(0.448)\end{array}$ & $\begin{array}{l}-1.086 * * \\
(0.476)\end{array}$ & $\begin{array}{l}-1.217 * * * \\
(0.452)\end{array}$ & $\begin{array}{l}-0.991 * * \\
(0.458)\end{array}$ & $\begin{array}{l}-2.843^{*} \\
(1.535)\end{array}$ & $\begin{array}{c}-1.293 * * * \\
(0.444)\end{array}$ & $\begin{array}{l}-1.055 * * \\
(0.450)\end{array}$ \\
\hline PREF*FL & $\begin{array}{l}0.278 * * * \\
(0.083)\end{array}$ & $\begin{array}{l}0.304 * * \\
(0.120)\end{array}$ & $\begin{array}{l}0.272 * * * \\
(0.083)\end{array}$ & $\begin{array}{l}0.240 * * * \\
(0.088)\end{array}$ & $\begin{array}{l}0.223 * * \\
(0.093)\end{array}$ & $\begin{array}{l}0.288 * * * \\
(0.085)\end{array}$ & $\begin{array}{l}0.252 * * * \\
(0.089)\end{array}$ \\
\hline FL & $\begin{array}{l}-0.059 \\
(0.040)\end{array}$ & $\begin{array}{l}-0.073 \\
(0.049)\end{array}$ & $\begin{array}{l}-0.046 \\
(0.050)\end{array}$ & $\begin{array}{l}-0.057 \\
(0.039)\end{array}$ & $\begin{array}{l}-0.059 \\
(0.039)\end{array}$ & $\begin{array}{l}-0.024 \\
(0.044)\end{array}$ & $\begin{array}{l}-0.036 \\
(0.039)\end{array}$ \\
\hline Output gap & $\begin{array}{l}0.037 * \\
(0.022)\end{array}$ & $\begin{array}{l}0.036 \\
(0.023)\end{array}$ & $\begin{array}{l}0.029 \\
(0.025)\end{array}$ & $\begin{array}{l}0.035 \\
(0.021)\end{array}$ & $\begin{array}{l}0.039^{*} \\
(0.021)\end{array}$ & $\begin{array}{l}0.039 * \\
(0.023)\end{array}$ & $\begin{array}{l}0.033 \\
(0.021)\end{array}$ \\
\hline Change in output gap & $\begin{array}{l}-0.000 \\
(0.007)\end{array}$ & $\begin{array}{l}-0.001 \\
(0.007)\end{array}$ & $\begin{array}{l}-0.010 \\
(0.009)\end{array}$ & $\begin{array}{l}-0.001 \\
(0.007)\end{array}$ & $\begin{array}{l}-0.000 \\
(0.007)\end{array}$ & $\begin{array}{l}0.000 \\
(0.006)\end{array}$ & \\
\hline Change in gov. bal. & $\begin{array}{l}0.006 \\
(0.006)\end{array}$ & $\begin{array}{l}0.005 \\
(0.007)\end{array}$ & $\begin{array}{l}0.005 \\
(0.006)\end{array}$ & $\begin{array}{l}0.003 \\
(0.006)\end{array}$ & $\begin{array}{l}0.001 \\
(0.007)\end{array}$ & $\begin{array}{l}0.012 \\
(0.007)\end{array}$ & \\
\hline Change in inflation & $\begin{array}{l}-0.046^{* * *} \\
(0.019)\end{array}$ & $\begin{array}{l}-0.040 * * \\
(0.018)\end{array}$ & $\begin{array}{l}-0.030 \\
(0.021)\end{array}$ & $\begin{array}{l}-0.045 * * \\
(0.019)\end{array}$ & $\begin{array}{l}-0.042 * * \\
(0.019)\end{array}$ & $\begin{array}{l}-0.065 \\
(0.051)\end{array}$ & \\
\hline Median age & $\begin{array}{l}-0.077 * * * \\
(0.029)\end{array}$ & $\begin{array}{l}-0.103 * * * \\
(0.026)\end{array}$ & $\begin{array}{l}-0.094 * * * \\
(0.029)\end{array}$ & $\begin{array}{l}-0.097 * * * \\
(0.023)\end{array}$ & $\begin{array}{l}-0.108 * * * \\
(0.026)\end{array}$ & $\begin{array}{l}-0.110 * * * \\
(0.029)\end{array}$ & $\begin{array}{l}-0.097 * * * \\
(0.028)\end{array}$ \\
\hline GDP level & $\begin{array}{l}-0.000 \\
(0.000)\end{array}$ & & & & & & \\
\hline PREF*GDP level & $\begin{array}{l}-0.000 \\
(0.000)\end{array}$ & & & & & & \\
\hline GDP pc level & & $\begin{array}{l}0.003 \\
(0.008)\end{array}$ & & & & & \\
\hline PREF*GDP pc level & & $\begin{array}{l}-0.006 \\
(0.012)\end{array}$ & & & & & \\
\hline Unemployment rate & & & $\begin{array}{l}-0.009 \\
(0.015)\end{array}$ & & & & \\
\hline Government debt & & & & $\begin{array}{l}-0.000 \\
(0.001)\end{array}$ & & & \\
\hline PREF*median age & & & & & $\begin{array}{l}0.051 \\
(0.040)\end{array}$ & & \\
\hline $\begin{array}{l}\text { Change in output gap } \\
\text { Lagged }\end{array}$ & & & & & & $\begin{array}{l}-0.011 \\
(0.008)\end{array}$ & \\
\hline $\begin{array}{l}\text { Change in gov. bal. } \\
\text { Lagged }\end{array}$ & & & & & & $\begin{array}{l}0.016 \\
(0.010)\end{array}$ & \\
\hline $\begin{array}{l}\text { Change in inflation } \\
\text { Lagged }\end{array}$ & & & & & & $\begin{array}{l}0.039 \\
(0.043)\end{array}$ & \\
\hline $\begin{array}{l}\text { Change in output gap } \\
\text { over } 4 \text { years }\end{array}$ & & & & & & & $\begin{array}{l}0.003 \\
(0.003)\end{array}$ \\
\hline $\begin{array}{l}\text { Change in gov. bal. } \\
\text { over } 4 \text { years }\end{array}$ & & & & & & & $\begin{array}{l}-0.004 \\
(0.003)\end{array}$ \\
\hline $\begin{array}{c}\text { Change in inflation } \\
\text { over } 4 \text { years }\end{array}$ & & & & & & & $\begin{array}{l}-0.005 \\
(0.010) \\
\end{array}$ \\
\hline Observations & 107 & 107 & 100 & 105 & 107 & 102 & 103 \\
\hline
\end{tabular}

Notes: Robust standard errors in parentheses. $(*),(* *)$, and $(* * *)$ denote significance at the (10), (5), and (1) per cent level. All the specifications include controls for political conditions, time effects, and a constant, not reported. 2SLS estimates. As the baseline model, we consider the IV specification in column 6 of Table 2, which includes as explanatory variables in the second-stage regression all the macro-economic, demographic, and political control variables listed in column 3 of Table 1, as well as year fixed effects.

Source: See the Data Appendix. 
Table 4. Robustness checks - political conditioning factors.

\begin{tabular}{|c|c|c|c|c|c|c|c|}
\hline \multirow{2}{*}{$\begin{array}{l}\text { Dependent variable: } \\
\text { Estimator: }\end{array}$} & \multicolumn{5}{|c|}{ Re-election of the head of the government } & \multicolumn{2}{|c|}{$\begin{array}{r}\text { Re-elec.of the head } \\
\text { of the gov. from } \\
\text { the same party }\end{array}$} \\
\hline & 2 SLS & 2 SLS & 2 SLS & 2 SLS & 2 SLS & 2 SLS & 2SLS \\
\hline & $(1)$ & $(2)$ & $(3)$ & (4) & $(5)$ & $(6)$ & $(7)$ \\
\hline PREF & $\begin{array}{l}-1.346 * * \\
(0.603)\end{array}$ & $\begin{array}{l}-0.972 * * \\
(0.468)\end{array}$ & $\begin{array}{l}-1.000 * * \\
(0.478)\end{array}$ & $\begin{array}{l}-0.982 * * \\
(0.418)\end{array}$ & $\begin{array}{l}-1.345^{* *} \\
(0.614)\end{array}$ & $\begin{array}{l}-1.202 * * * \\
(0.393)\end{array}$ & $\begin{array}{l}-0.913 * * \\
(0.419)\end{array}$ \\
\hline PREF*FL & $\begin{array}{l}0.257 * * * \\
(0.090)\end{array}$ & $\begin{array}{l}0.256 * * * \\
(0.090)\end{array}$ & $\begin{array}{l}0.244 * * * \\
(0.095)\end{array}$ & $\begin{array}{l}0.227 * * * \\
(0.088)\end{array}$ & $\begin{array}{l}0.274 * * * \\
(0.082)\end{array}$ & $\begin{array}{l}0.266 * * * \\
(0.078)\end{array}$ & $\begin{array}{l}0.230 * * * \\
(0.076)\end{array}$ \\
\hline FL & $\begin{array}{l}-0.059 \\
(0.039)\end{array}$ & $\begin{array}{l}-0.053 \\
(0.040)\end{array}$ & $\begin{array}{l}-0.048 \\
(0.041)\end{array}$ & $\begin{array}{l}-0.058 \\
(0.041)\end{array}$ & $\begin{array}{l}-0.078^{*} \\
(0.041)\end{array}$ & $\begin{array}{l}-0.047 \\
(0.040)\end{array}$ & $\begin{array}{l}-0.022 \\
(0.041)\end{array}$ \\
\hline Margin of majority & $\begin{array}{l}0.809 * \\
(0.477)\end{array}$ & $\begin{array}{l}0.857 * \\
(0.472)\end{array}$ & $\begin{array}{l}0.820 * \\
(0.476)\end{array}$ & $\begin{array}{l}0.767 * \\
(0.462)\end{array}$ & $\begin{array}{l}0.965 * * \\
(0.479)\end{array}$ & $\begin{array}{l}0.780 * * \\
(0.477)\end{array}$ & $\begin{array}{l}0.698 \\
(0.477)\end{array}$ \\
\hline Left-oriented & $\begin{array}{l}0.086 \\
(0.097)\end{array}$ & $\begin{array}{l}0.110 \\
(0.111)\end{array}$ & $\begin{array}{l}0.106 \\
(0.102)\end{array}$ & $\begin{array}{l}0.133 \\
(0.097)\end{array}$ & $\begin{array}{l}0.039 \\
(0.101)\end{array}$ & $\begin{array}{l}0.077 \\
(0.096)\end{array}$ & $\begin{array}{l}0.067 \\
(0.090)\end{array}$ \\
\hline Stability & $\begin{array}{l}-0.778 * * \\
(0.309)\end{array}$ & $\begin{array}{l}-0.799 * * * \\
(0.308)\end{array}$ & $\begin{array}{l}-1.028 * * * * \\
(0.292)\end{array}$ & $\begin{array}{l}-0.819 * * \\
(0.325)\end{array}$ & $\begin{array}{l}-0.727 \text { *** } \\
(0.273)\end{array}$ & $\begin{array}{l}-0.723 * * \\
(0.319)\end{array}$ & $\begin{array}{l}-0.527^{*} \\
(0.301)\end{array}$ \\
\hline $\mathrm{PREF}^{*}$ margin majority & $\begin{array}{l}0.572 \\
(1.153)\end{array}$ & & & & & & \\
\hline PREF*left-oriented & & $\begin{array}{l}-0.128 \\
(0.247)\end{array}$ & & & & & \\
\hline PREF*stability & & & $\begin{array}{l}0.975 \\
(0.843)\end{array}$ & & & & \\
\hline Polarization & & & & $\begin{array}{l}0.009 \\
(0.061)\end{array}$ & & & \\
\hline PREF*polarization & & & & $\begin{array}{l}0.113 \\
(0.122)\end{array}$ & & & \\
\hline Change ODR & & & & & $\begin{array}{l}-0.019 * * \\
(0.009)\end{array}$ & & \\
\hline Change DR*FF & & & & & $\begin{array}{l}0.034 \\
(0.025)\end{array}$ & & \\
\hline FF (fully funded) & & & & & $\begin{array}{l}-0.622 \\
(0.580)\end{array}$ & & \\
\hline PREF*change ODR & & & & & $\begin{array}{l}0.011 \\
(0.019)\end{array}$ & & \\
\hline PREF*change ODR*FF & & & & & $\begin{array}{l}-0.011 \\
(0.013)\end{array}$ & & \\
\hline Max. years of office & & & & & & $\begin{array}{l}0.013 \\
(0.013)\end{array}$ & \\
\hline Beginning of legisl. & & & & & & $\begin{array}{l}0.065 \\
(0.166)\end{array}$ & \\
\hline Observations & 107 & 107 & 107 & 104 & 107 & 107 & 107 \\
\hline
\end{tabular}

Notes: Robust standard errors in parentheses. $(*),(* *)$, and $(* * *)$ denote significance at the (10), (5), and (1) per cent level. All the specifications include controls for macroeconomic and demographic conditions, time effects, and a constant, not reported. 2SLS estimates. As the baseline model, we consider the IV specification in column 6 of Table 2, which includes as explanatory variables in the second-stage regression all the macro-economic, demographic, and political control variables listed in column 3 of Table 1, as well as year fixed effects.

Source: See the Data Appendix. 
Table 5. Financial literacy and other indicators of education.

\begin{tabular}{|c|c|c|c|c|c|c|c|}
\hline \multirow{2}{*}{$\begin{array}{l}\text { Dependent variable: } \\
\text { Estimator: }\end{array}$} & \multicolumn{7}{|c|}{ Re-election of the head of the government } \\
\hline & 2SLS & 2SLS & 2SLS & 2SLS & $2 \mathrm{SLS}$ & 2 SLS & 2SLS \\
\hline & $(1)$ & $(2)$ & $(3)$ & $(4)$ & $(5)$ & $(6)$ & $(7)$ \\
\hline PREF & $\begin{array}{l}-1.140 * * \\
(0.471)\end{array}$ & $\begin{array}{l}-1.069 * * * \\
(0.414)\end{array}$ & $\begin{array}{l}-0.823 * \\
(0.435)\end{array}$ & $\begin{array}{l}-9.783^{* * * *} \\
(1.723)\end{array}$ & $\begin{array}{l}-1.816 \\
(2.370)\end{array}$ & $\begin{array}{l}0.613 \\
(1.217)\end{array}$ & $\begin{array}{l}0.411 \\
(0.693)\end{array}$ \\
\hline PREF*FL av. over $\mathrm{t}$ and $\mathrm{t}-1$ & $\begin{array}{l}0.277 * * * \\
(0.092)\end{array}$ & & & & & & \\
\hline FL averaged over $t$ and $t-1$ & $\begin{array}{l}-0.049 \\
(0.038)\end{array}$ & & & & & & \\
\hline PREF*FL yearly value & & $\begin{array}{l}0.265 * * * \\
(0.080)\end{array}$ & $\begin{array}{l}0.208 * * \\
(0.089)\end{array}$ & & & & \\
\hline FL yearly value & & $\begin{array}{l}-0.058 \\
(0.038)\end{array}$ & $\begin{array}{l}-0.023 \\
(0.044)\end{array}$ & & & & \\
\hline PREF*OECD FL in 2015 & & & & $\begin{array}{l}0.020 * * * \\
(0.004)\end{array}$ & & & \\
\hline OECD FL in 2015 & & & & $\begin{array}{l}-0.026 * * * \\
(0.004)\end{array}$ & & & \\
\hline PREF*PISA score in maths & & & & & $\begin{array}{l}0.004 \\
(0.005)\end{array}$ & & \\
\hline PISA score in maths & & & & & $\begin{array}{l}0.007 * \\
(0.004)\end{array}$ & & \\
\hline PREF*secondary school att. & & & & & & $\begin{array}{l}-0.006 \\
(0.021)\end{array}$ & \\
\hline Secondary school attainment & & & & & & $\begin{array}{l}-0.003 \\
(0.006)\end{array}$ & \\
\hline PREF*tertiary school att. & & & & & & & $\begin{array}{l}-0.005 \\
(0.034)\end{array}$ \\
\hline Tertiary school attainment & & & & & & & $\begin{array}{l}-0.003 \\
(0.011)\end{array}$ \\
\hline Observations & 107 & 107 & 74 & 36 & 45 & 107 & 107 \\
\hline
\end{tabular}

Notes: Robust standard errors in parentheses. $(*),(* *)$, and $(* * *)$ denote significance at the (10), (5), and (1) per cent level. All the specifications include controls for macroeconomic, demographic, and political conditions, time effects, and a constant, not reported. 2SLS estimates. As the baseline model, we consider the IV specification in column 6 of Table 2, which includes as explanatory variables in the second-stage regression all the macro-economic, demographic, and political control variables listed in column 3 of Table 1, as well as year fixed effects.

Source: See the Data Appendix. 